\title{
Unikalne warunki pracy łożysk wałeczkowych w kolejowym systemie przestawczym „,UIC - ОСЖД” wg patentów B1: 201613 [1] oraz 202614 [2]
}

\begin{abstract}
$W$ artykule przedstawiono i przedyskutowano mechaniczna koncepcje systemu przestawczego „UIC - ОСЖД” w zakresie pracy rozsuwanego zestawu kołowego $i$ odpowiedniego stanowiska przestawczego. Przeprowadzono dyskusje pracy tożysk wateczkowych $w$ ruchowych warunkach przełaczania rozstawu bieżni rolek. Przedstawiono wyniki badań eksperymentalnych na modelu redukcyjnym. W zakończeniu podano wnioski praktyczne
\end{abstract}

\section{Ogólna charakterystyka pracy lożysk wałeczko- wych $w$ procesie zmiany rozstawu kól $w$ zestawie rozsuwnym według patentów [1] i [2]}

Zestaw ma nieruchomą oś 1 , na której zostały spoczynkowo osadzone wewnętrzne pierścienie łożysk wałeczkowych 2. Zewnętrzne pierścienie tych łożysk znajdują się w kołach biegowych 3. Pierścienie te mają bieżnię tak poszerzona, że przesuwne koło biegowe 3, w swych skrajnych położeniach może współpracować zarówno z torem $1435 \mathrm{~mm}$ jak i z torem $1520 \mathrm{~mm}$. Do każdego koła biegowego 3 zostało przyłączone poosiowo przesuwne sprzęgło 4 , z którego moment obrotowy jest przekazywany na wspólny wał drazżony 5 . W ten sposób obydwa koła biegowe 3, niezależnie od rozstawu kół, pracują w warunkach obrotowego sprzężenia. Sztywność skrętna pomiędzy kołami biegowymi nie zależy od nastawionego rozstawu kół. W ten sposób zostało zapewnione klasyczne, bezluzowe i stabilne prowadzenie zestawu w torze za pomocą podłużnych sił przyczepności pomiędzy kołami a szynami. Omawiany zestaw rozsuwny w wykonaniu wagonowym umożliwia zastosowanie hamulców tarczowych i nadaje się też do pojazdów trakcyjnych (rys. 2) hamowanych elektrodynamicznie oraz ciernie na kołach biegowych, na przykład klockowo.

Zgodnie z rysunkami 1 i 2 unikalny charakter pracy łożysk wałeczkowych występuje w procesie zmiany rozstawu kół biegowych w obrębie stanowiska przestawczego, gdy wałeczki łożyskowe muszą doznać przemieszczenia poosiowego przy zmianie pierścieniowej bieżni (zewnętrznej lub wewnętrznej). Ze względu na niewielki rozstaw łożysk w kołach biegowych nie jest możliwe przesunięcie promieniowo obciążonych kół biegowych przez zwyczajne przyłożenie bocznych sił do pierścienia biegowego podczas postoju pojazdu. Albowiem statyczny układ natychmiast ulegnie zakleszczeniu, gdyż jest samohamowny.
Tematem niniejszego artykułu jest ruchowe zjawisko bocznego poślizgu („boczne znoszenie”) rolek łożyskowych, określające parametry stanowiska przestawczego UIC - ОСЖД według rysunku 3.

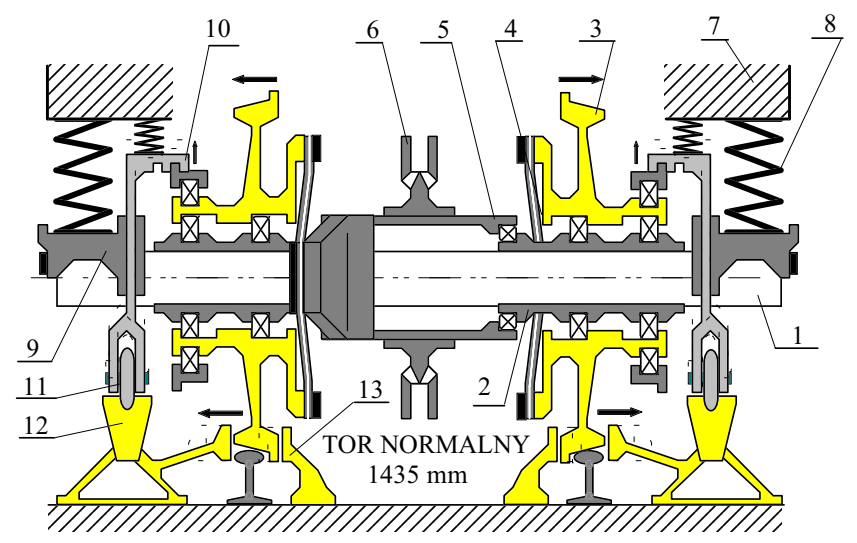

Rys. 1. Schemat budowy zestawu o zmiennym rozstawie kół

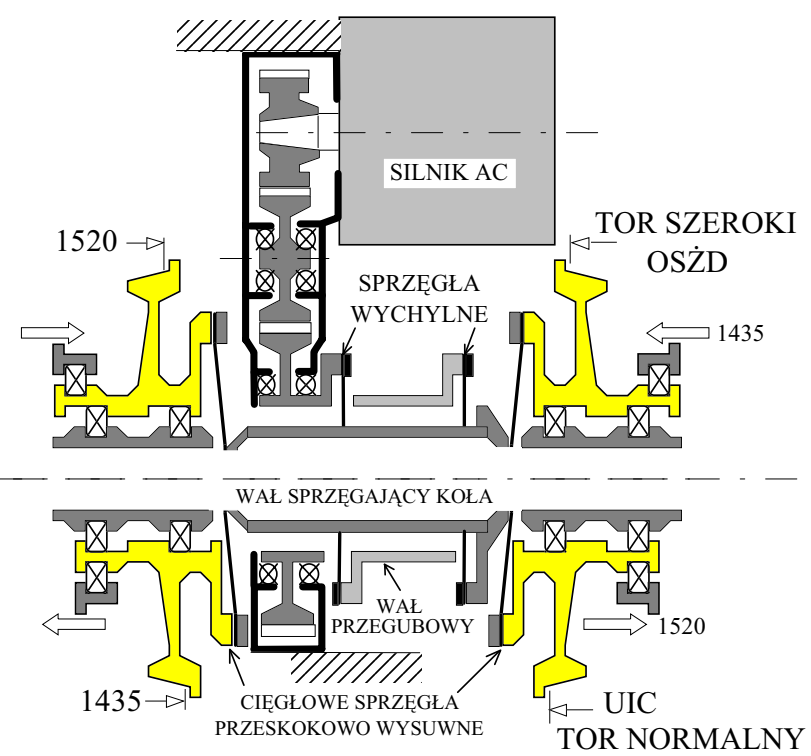

Rys. 2. Schemat budowy zestawu o zmiennym rozstawie kół w pojeździe trakcyjnym 


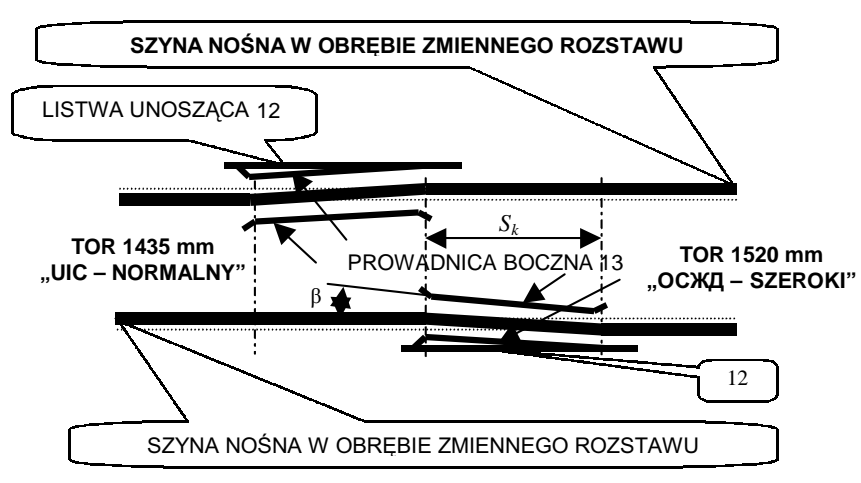

Rys. 3. Układ szyn nośnych, listew unoszących 12 i prowadnic sterujących 13 stanowiska w systemie przestawczym „miękki przesuw - soft-shift"

Rozstaw biegowych kół zestawu na całym obszarze określonego zarządu kolejowego jest zaryglowany za pomocą zatrzasku 11. Tylko na granicy zarządów, $\mathrm{w}$ infrastrukturze torowej występują pionowe i boczne prowadnice sterujące 12 oraz 13 jedynie w obrębie stanowiska przestawczego. Podczas ruchu pojazdu w torze pionowa pochylnia 12 unosi rygiel 11 węzła osiowego, zaś poziome listwy prowadzące 12 lub 13 powodują rozsuwanie lub zwężanie rozstawu kół. Po zakończeniu procesu przestawczego obniża się pionowa pochylnia 12 umożliwiając ponowne opuszczenie zatrzasku rygla $11 \mathrm{ku}$ dołowi, pozycjonując korpus łożyska w nowym położeniu odpowiednio do rozstawu szyn.

Użytkowym celem niniejszego artykułu jest wyznaczenie wytycznych do projektu stanowiska przestawczego. Dla technicznej płynności procesu przestawczego proponuje się przemieszczanie kół zestawu o 42,5 mm kolejno, nie równocześnie. Stąd na schemacie układu toków szynowych występują dwa odcinki bocznych listew unoszących 12 oraz prowadnic bocznych 13. Zadanie inżynierskie brzmi: „Jaka powinna być racjonalna długość prowadnic bocznych 13 "?

\section{Istota technicznej unikalności omawianych wa- runków pracy lożysk}

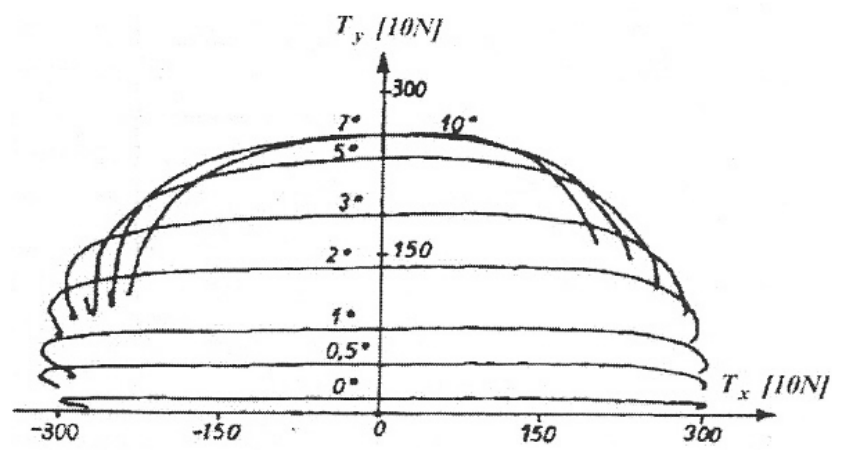

Zjawisko bocznego znoszenia kót (lub rolek nośnych) jest od wielu już lat dobrze technicznie rozpoznane i w literaturze np. [3] jest prezentowane na wykresach wartości granicznych poprzecznych sił przyczepności (na kierunku y) w stosunku do granicznych sił trakcyjnych (na kierunku $x$ ) $F_{y}\left(F_{x}\right)$ albo też $\mathrm{w}$ ujęciu względnych przyśpieszeń $\mathrm{w}$ polu grawitacyjnym $g ; a_{y} / g\left(a_{x} / g\right)$.

Omawiane zjawisko jest spotykane powszechnie. Obserwujemy je podczas prowadzenia czterokołowego klasycznego wózka dziecięcego (ze sztywnymi osiami) w krętej alejce parkowej, wchodząc gwałtownie samochodem w zakręt, jak też podczas ruchu kół skręcającej wieloosiowej naczepy TIR-a. Natomiast boczny poślizg rolek łożyskowych (przy tzw. „przekoszeniu rolek") jest w technice na ogół traktowany jako bardzo szkodliwy i daje się on wyeliminować przez zastosowanie koszyków łożyskowych zapewniających obracanie się rolek ściśle wokół osi równoległych do osi łożyska. Przypadek techniczny omawiany w niniejszym artykule nie dotyczy przekoszenia rolek. Osie rolek mają zawsze pozostawać w pozycji równoległej w stosunku do osi łożyska.

Wszystkie rozpoznane (i przebadane) przypadki bocznego znoszenia kót lub rolek na stanowiskach badawczych (rys. 4) dotyczyły fizycznych obszarów niesamohamowności, gdy układ nie mógł ulec zakleszczeniu. Natomiast w omawianym tu przypadku boczne znoszenie rolek tożyskowych (ruchowe odchylenie trajektorii rolek) jest wymagane jako użyteczny czynnik techniczny w unikalnych warunkach statycznego samo-zakleszczania się, gdy tylko podczas ruchu układu stosunek siły bocznego znoszenia do nacisku normalnego osiagnie graniczną wartość współczynnika tarcia. Zatem w naszym przypadku mamy do czynienia $\mathrm{z}$ unikalnym ruchowym przypadkiem bocznego znoszenia rolek tożyskowych zawsze prowadznych przez koszyk łożyskowy poprawnie, w równoległej pozycji osi rolek w stosunku do osi łożyska. Na to technicznie rzadkie zjawisko składa się zarówno (a) ruchowy „śrubowy” proces znoszenia bezpoślizgowego jak też poślizg wyłącznie poosiowy (b) każdej ruchomej rolki przy technicznie oczywistym braku

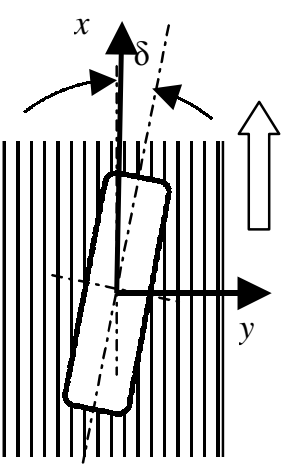
jakiegokolwiek jej obciążenia skierowanego obwodowo. Przedstawiona na rys. 4 ,elipsa tarcia" pozwala na wyodrębnienie przypadku (b) w warunkach granicznych, przy $T_{x}=0$. Teraz przyjrzymy się przypadkowi (a).

Rys. 4. „Elipsa tarcia” według [3]. Obok ilustracja warunków toczenia się rolki po bieżni 


\section{Wpływ sprężystych deformacji ścinających w wałeczkowej rolce łożyskowej na jej bezpośli- zgowe zaburzenie trajektorii ruchu w kierunku poosiowym}

W patentowanych rozwiazzaniach konstrukcyjnych według rys. 1 i 2 węzły łożyskowania kół zestawów na ogół (z konieczności) mają przez konstruktora narzuconą (w statycznych warunkach postojowych) zdolność poosiowego samo-zakleszczania się: $2 b<<$ $\mu D$, (czyli samohamowność narzuconą geometrycznie). W takich warunkach ewentualne poosiowe przemieszczenia rolek na bieżni w łożysku wałeczkowym mogą zachodzić $\mathrm{z}$ określonymi prędkościami tylko w warunkach ruchowych.

Nie można bezdyskusyjnie dokonać przeniesienia wyników badań w warunkach wykluczających samohamowność (rys. 4) na warunki immanentnej samohamowności (według geometrii rys. 1 i 2). Rysunek 4 przedstawia krzywe graniczne odpowiadające ruchowemu tarciu rozwiniętemu już po wyczerpaniu wstępnego procesu mikropoślizgowego. $\mathrm{W}$ technice moga być wykorzystywane też wartości sił wewnątrz pól eliptycznych, odpowiadające ruchowym procesom mikropoślizgowym. Czerpiąc dane $\mathrm{z}$ wykresu przedstawionego na rysunku 4 możemy sporządzić wykres we współrzędnych $T_{y}(\delta)$ przy wartościach $T_{x}=0-$ gdzie jako $\delta$ oznaczono kąt ruchowego odchylenia trajektorii rolki od kierunku obwodowego na bieżni. $\mathrm{W}$ ten sposób uzyskujemy rys. 5, przedstawiający charakterystykę procesu

ruchowego narastania poosiowych sił przyczepności rolki $F_{y}$ ze wzrostem narzucanego kąta $\delta$, aż do granicznych warunków tarcia. Jednak w naszym przypadku o tarciu nawet nie może być mowy, gdyż - jak wspomniano - układ jest samo-zakleszczający się (samohamowny). O tym nie możemy zapominać.

W procesie zmiany rozstawu okręgów tocznych zestawu kołowego rolka łożyska wałeczkowego zostaje obciążona siłą $F_{y}$, działającą od strony listwy prowadzącej 13. Siła ta - według rysunku 6 - wywołuje następstwa kontaktowe $\mathrm{w}$ postaci zarówno krawędziowego zaburzenia $\Delta Q$ rozkładu nacisków roboczych $Q$, jak też określone ścinające odkształcenia sprężyste w rolce.

Zjawisko kontaktowe na obydwóch końcach rolki ma charakter poosiowo symetryczny. Siły kontaktowe w obrębie rolki na kierunku poosiowym równoważą się statycznie. Mają one istotny związek z mikropoślizgiem poprzecznym, traktowanym tu jako składowa poślizgu dwuwymiarowego, podłużnie - poprzecznego, (gdy poślizg podłużny - na kierunku $x$ - w naszym szczególnym przypadku nie występuje). Dlatego poniżej zajmiemy się wyłącznie odkształceniami ścinającymi i ich następstwami w bezpoślizgowym ruchu sprężyście odkształconej rolki po bieżni.

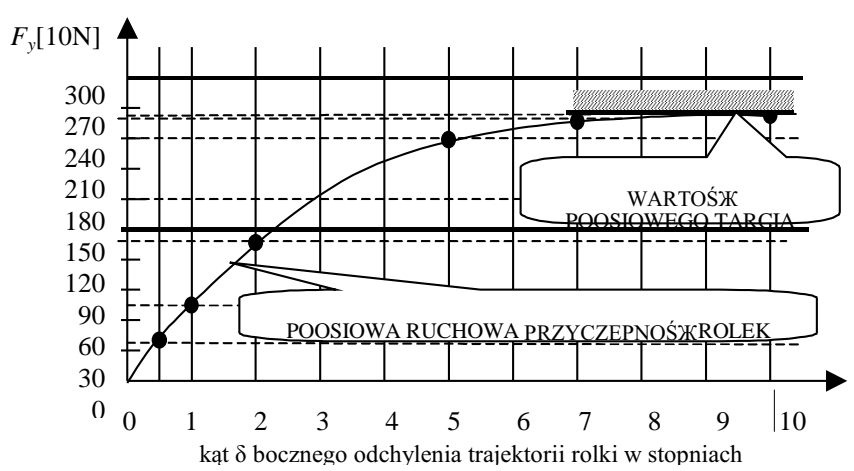

Rys. 5. Krzywa nasycenia przyczepności poprzecznej siły $F_{y}$ W funkcji kąta znoszenia, (przekoszenia) aż do osiągnięcia granicznej siły tarcia, sporządzona według rys. 4

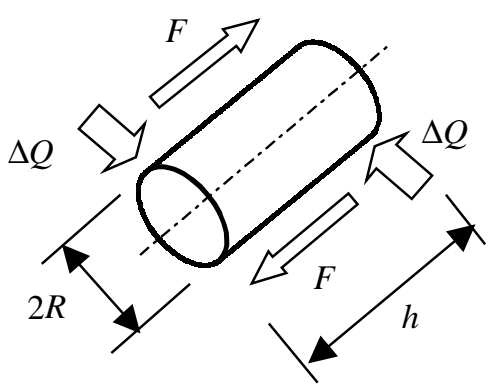

Rys. 6. Stan obciążeń zewnętrznych pojedynczej rolki łożyska wałeczkowego

Zgodnie z rysunkiem 7 możemy napisać

$$
\begin{aligned}
& d \zeta=R \sin \Theta d \Theta \\
& S=2 R \sin \Theta
\end{aligned}
$$

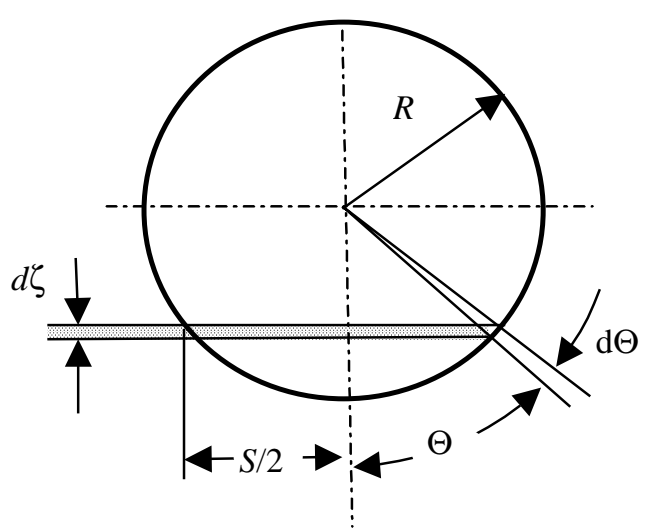

Rys. 7. Elementarna warstwa ścinana w obrębie rolki: $[h \times S \times \mathrm{d} \zeta]$

Kąt $\gamma$ odkształcenia postaciowego w obrębie elementarnej warstewki d $\zeta$ zależy od wartości obciążenia ścinającego $F$, modułu odkształcenia postaciowego $G$ oraz powierzchni ścinania $A$, która jest funkcją kąta $\Theta$.

$$
\begin{aligned}
& \gamma(\Theta)=\frac{\tau(\Theta)}{G} ; \quad G=\frac{E}{2(1+\nu)} ; \\
& \tau(\Theta)=\frac{F}{A(\Theta)} ; \quad A(\Theta)=h \cdot S(\Theta)
\end{aligned}
$$

gdzie:

$v$ - liczba Poissona,

$E$ - moduł Younga. 
Zatem w obrębie kąta $0<\Theta \leq \pi / 2$ wystapi poosiowe odkształcenie rolki według poniższego wzoru

$$
\frac{\varepsilon_{y}}{2}=\int_{0}^{R} \gamma(\Theta) \cdot d \zeta=F \frac{(1+v)}{h \cdot E} \int_{0}^{\pi / 2} \sin \Theta \cdot d \Theta=\frac{\pi \cdot F(1+v)}{2 E \cdot h}
$$

Stąd całkowite ścinające odkształcenie poosiowe na średnicy $2 R$ rolki wynosi

$$
\varepsilon_{y}=\frac{\pi \cdot F(1+v)}{E \cdot h}=\frac{\pi \cdot F}{2 h \cdot G}
$$

Na mocy powyższych rozważań widzimy, że zewnętrzny ślad odkształcenia okrągłej rolki, niezależnie od jej kierunku obracania się, ma zawsze charakter śrubowy, w widoku bocznym harmoniczny, (będacym them dla ruchu obrotowego rolki), co zilustrowano rys. 8.

Widzimy, że poosiowo bezpoślizgowa składowa prędkości śrubowego ruchu rolki stanowi kinematyczne następstwo obrotowo wędrujących naprężeń ścinających.

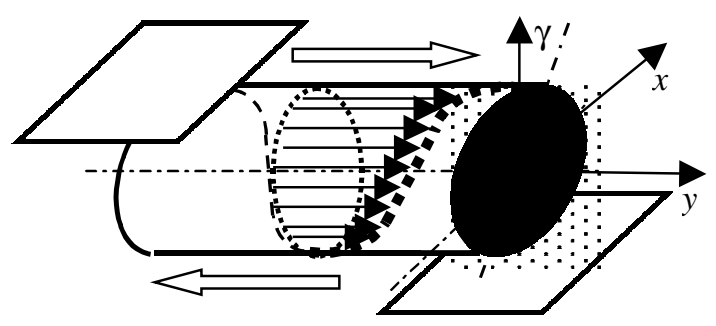

Rys. 8. Obraz odkształceń łożyskowej rolki obciążonej poosiowo

Średnica rolki $2 R$ nie występuje jawnie we wzorze (4), gdyż jako parametr wastwowej powierzchni ścinania (wg rys. 7) średnica ta nie ma wpływu na abstrakcyjny skok śrubowej linii sprężystych odkształceń rolki; (im mniejsza jest średnica rolki, tym większe jest pochylenie linii odkształceń sprężystych).

Według wzoru (4) wartość poosiowego obciążenia $F_{y}$ pojedynczej rolki wywiera proporcjonalny wpływ na przestawczą efektywność kolejowego zestawu według patentów [1] i [2]. Natomiast długość $h$ rolki wywiera wpływ odwrotnie proporcjonalny. Liczba $N$ rolek pracujących na bieżniach określonego łożyska jest odwrotnie proporcjonalna do ich średnicy $2 R$, podobnie jak odwrotnie proporcjonalna jest siła przypadająca na pojedynczą rolkę: im więcej jest cienkich rolek, tym mniejsza siła przypada na pojedynczą rolkę. Dlatego w omawianym systemie przestawczym łożyska igiełkowe stanowczo nie powinny być stosowane.

Dla merytorycznego porządku wykonamy proste obliczenia przykładowe.

Pełny skok umownej linii śrubowej wynosi $\varepsilon_{y}$. Dla łożysk stalowych $G \approx 7923 \cdot 10^{10} \mathrm{~N} / \mathrm{m}^{2}$. Według (4) otrzymujemy (w jednostkach SI) następującą wartość pełnego skoku abstrakcyjnej linii śrubowej poosiowych mikropoślizgów sprężystych pojedynczej rolki o dowolnej średnicy

$$
\varepsilon_{y}=3,965 \cdot 10^{-11} \frac{F}{h} \quad[\mathrm{~m} / \mathrm{obr}]
$$

Przy działaniu stosunkowo niewielkiej siły $F=10^{3}$ $\mathrm{N}$, gdy rolki łożyskowe mają na przykład długość $h=$ $0,02 \mathrm{~m}$, wtedy $\varepsilon_{y} \approx 1,32 \cdot 10^{-6} \mathrm{~m} / \mathrm{obr}$. Oznacza to, że dla wyczerpania poosiowego przemieszczenia $0,0425 \mathrm{~m}$, rolka powinna wokół własnej osi wykonać ok. 32197 obrotów, co przy średnicy rolki wynoszącej $0,0015 \mathrm{~m}$, wymagałoby aż 1136 obrotów koła, czyli przebycia ok. 3,57 kilometra przy średnicach okręgów tocznych wynoszących $1 \mathrm{~m}$. To są wielkości nie do przyjęcia $\mathrm{w}$ technicznych przestawczych zastosowaniach kolejnictwa.

Powyższa analiza pokazuje, że ilościowy wpływ sprężystej pracy rolek - składowa a) wyartykułowana w p. 2 - na odchylenie podstawowej trajektorii (,,poosiowe znoszenie") rolek łożyskowych jest znikomy. Ewentualne uwzględnienie tego wpływu byłoby technicznie zasadne jedynie przy ewentualnym badaniu wewnętrznej dynamiki łożyska wałeczkowego z punktu widzenia stateczności ruchu rolek, co nie jest tematem naszych rozważań.

\section{Eksperymentalne badanie ,bocznego znoszenia rolek" na stanowisku}

Badanie przeprowadzono $\mathrm{w}$ dość prymitywnych warunkach garażowych, na stanowisku zbudowanym przez autora według schematu pokazanego na rys. 9. W bezluzowym łożysku nieruchomej obudowy 1 obrotowo osadzono toczony wałek stalowy 2 o średnicy $19,2 \mathrm{~mm}$, stanowiący wewnętrzną bieżnię zespołu dwóch wałeczkowych łożysk firmy FAG $35 \times 15 \times 11$ (średnica zewn. - wewn. - szerokość). Każde łożysko ma 11 rolek o wymiarach $\phi 4,8 \times 6 \mathrm{~mm}$, prowadzonych w koszykach zapewniających równoległość osi każdej rolki do osi łożyska.

Korpusy 3 badanych łożysk zostały przyłączone do dźwigni $4 \mathrm{w}$ taki sposób, że rozstaw $b$ łożysk geometrycznie zapewnia samohamowność układu, oraz może być podczas pomiarów niezmienny, zaś nastawne promieniowe obciążenia $Q$ obydwóch zespołów łożysk są pod względem wartości bezwzględnej zawsze jednakowe i przeciwnie skierowane. Obciążenia $Q$ zespołów łożyskowych wywiązywane były dzięki działaniu grawitacyjnej siły $F$ na nastawnym ramieniu $L$ według rys. 9.

Ramię $L$ oraz rozstaw korpusów b zostały tak dobrane, że podczas pomiarów warunek samozakleszczania się układu, $b \ll \mu L$, był zawsze spełniony. Na wolnym końcu wałka 2 została osadzona korbka, za pomocą której ręcznie obracano ten wałek w gnieździe nieruchomej obudowy 1, a zarazem wewnątrz korpusów 3 badanych łożysk, zawsze o jedna- 
kowy kąt $\Theta$, będący dziesięciokrotnością $2 \pi$. Podczas obracania korbką wałka 2, łączne poosiowe siły $\mathrm{F}$, przyłożone na dźwigni 4, wywoływały w łożyskach wałeczkowych ruchowe przemieszczenia poosiowe. Przemieszczenia te były rejestrowane na podstawie wskazań czujnika przemieszczeń 5 , z dokładnością do setnej części milimetra. Każdy pomiar powtarzano wielokrotnie, przy czym wyniki podane $\mathrm{w}$ tabeli 1 stanowią średnią arytmetyczną poszczególnych wskazań. Na wartość $F$ składały się grawitacyjne oddziaływania: pochodzące od masy własnej $\mathrm{M}_{\mathrm{w}}=4$ $\mathrm{kg}$, skupionej w dźwigni 4 na ramieniu $420 \mathrm{~mm}$, oraz od masy dodatkowej $M_{D}=5 \mathrm{~kg}$ na ramieniu nastawnym $L$. Pojedynczy zespół łożyskowy został pokazany na fot. 1 .

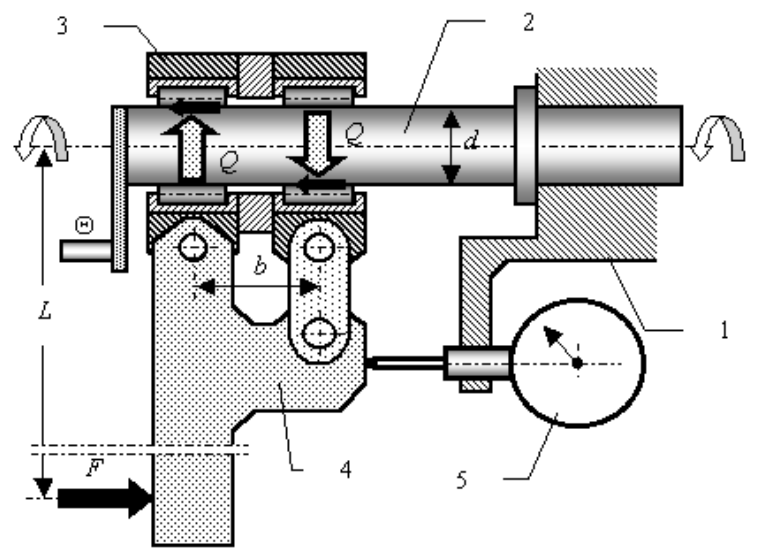

Rys. 9. Schemat kompletnego stanowiska badawczego

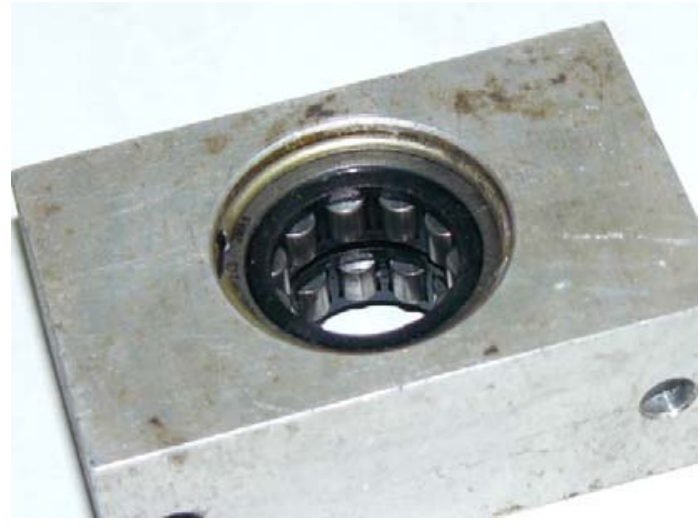

Fot. 1. Zespół dwóch łożysk wałeczkowych we wspólnym korpusie 3

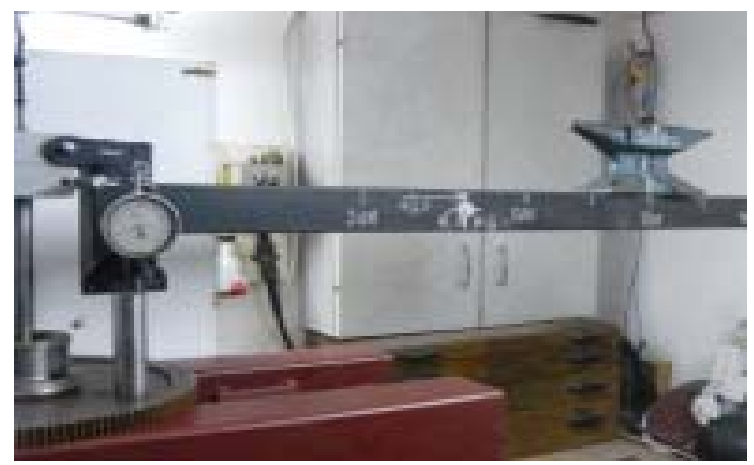

Fot. 2. Ogólny widok stanowiska pomiarowego
Na fotografii 2 pokazano widok ogólny stanowiska zaś na fotografii 3 przedstawiono badany węzeł łożyskowy wraz z czujnikiem przemieszczenia poosiowego. Podczas pomiarów rejestrowano wartości parametru $L$, oraz czujnikowy odczyt poosiowego przemieszczenia ruchowego $\Delta$ rolek łożysk 3 wzdłuż osi wałka 2 . W wynikach pomiarów, podanych $\mathrm{w}$ tabeli 1 , zawarto średnie wartości z 8 zarejestrowanych wyników pomiarów. Podczas pomiarów siły promieniowe w dwułożyskowych zespołach wahały się $\mathrm{w}$ granicach od $550 \mathrm{~N}$ do $2021 \mathrm{~N}$ zatem przy poosiowym statycznym obciążeniu rolek na granicy tarcia ze współczynnikiem $\mu \approx 0,3$, można byłoby przyłożyć siły od 165 do 606,3 N. Jednak ze względu na trudną do wyeliminowania sprężystą odkształcalność wałka 2 na zginanie, siła $\mathrm{F}$, przyłożona do układu podczas pomiarów, wynosiła zaledwie $\sim 88,3 \mathrm{~N}$. Zatem $\mathrm{z}$ warunków badań wynika, że wszystkie pomiary przeprowadzono z około dwukrotnym niewykorzystaniem statycznych granicznych wartości stosunku $F / Q$ zespołu łożyskowego. Niemniej jednak układ zawsze pozostawał w stanie statycznej samohamowności.

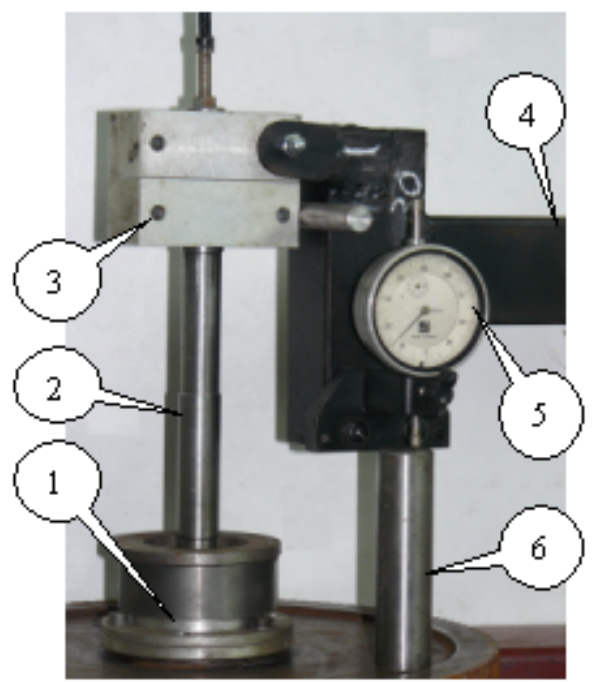

Fot. 3. Badany węzeł łożyskowy. Wałek dystansowy 6 podpiera krótką nóżkę czujnika 5

\section{Wyniki pomiarów}

Wyniki pomiarów zestawiono w tabeli 1 .

Wielkość $\delta \%$ opisuje kąt bocznego odchylenia trajektorii rolki podczas powolnego, ręcznego obracania wałka 2 o średnicy $d=19,2 \mathrm{~mm}$

$$
\delta[\%]=\frac{100 \cdot \Delta}{\pi \cdot d}
$$

Uśrednione (według zasady minimum sumy kwadratu błędów) przebiegi liniowe $\delta(\varphi)$ oraz $\delta(1 / \varphi)$ przedstawiono na rys. $10 \mathrm{i} 11$. Widzimy wyraźnie, że w przypadku badawczym boczne odchylenie trajektorii rolki rośnie wraz ze wzrostem wartości współczynnika $\varphi$ i maleje wraz ze wzrostem obciążenia promieniowego $Q$. 
Tabela 1

\begin{tabular}{|c|c|c|c|c|c|c|c|}
\hline$\varphi=F / Q$ & 0,0714 & 0,0847 & 0,0646 & 0,0437 & 0,032 & 0,047 & 0,066 \\
\hline $\begin{array}{c}\Delta \\
{[\mathrm{mm} / 10 \mathrm{obr}]}\end{array}$ & 4,435 & 3,465 & 2,44 & 2,545 & 1,867 & 2,25 & 2,16 \\
\hline$\delta[\%]$ & 7,355 & 5,746 & 4,046 & 4,22 & 3,096 & 3,75 & 3,58 \\
\hline$\delta^{\circ}$ & 4,206 & 3,288 & 2,316 & 2,416 & 1,773 & 2,147 & 2,050 \\
\hline
\end{tabular}

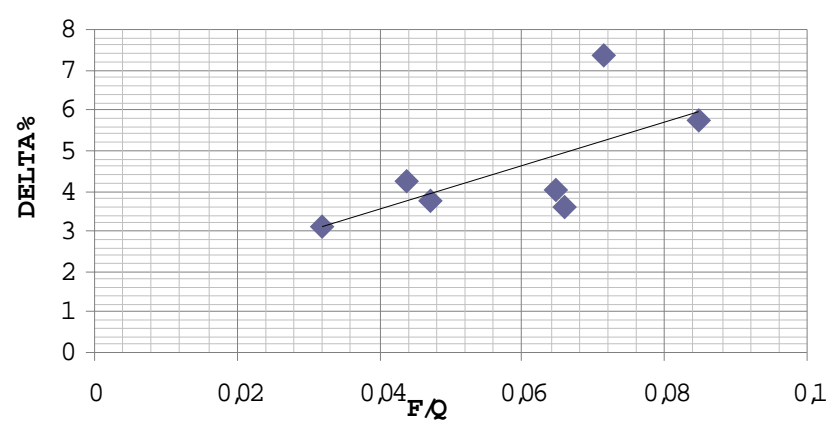

Rys. 10. Kąt $\delta$ odchylenia trajektorii rolki w funkcji obciążenia poosiowego $F$, gdy $Q=$ const

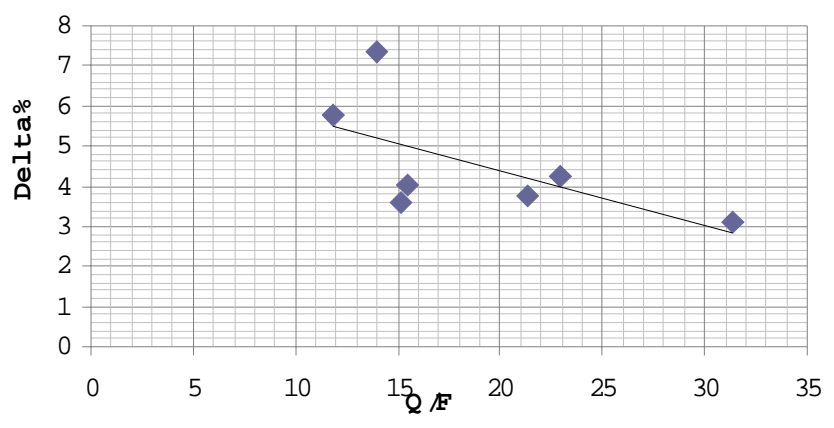

Rys. 11. Kąt $\delta$ odchylenia trajektorii rolki w funkcji obciążenia promieniowego $Q$ gdy $F_{y}=$ const

\section{Przeliczenie kąta odchylenia trajektorii rolki na parametry kolejowego stanowiska przestawczego}

Rolki łożyskowe poruszają się śrubowo po bieżni łożyska o średnicy $d_{b l} \mathrm{z}$ odchyleniem $\delta$ swej trajektorii, czyli na obwodzie koła zestawu kąt ten zmniejsza się odpowiednio do stosunku średnic bieżni łożyskowej i koła biegowego. Zatem dla wyczerpania koniecznego przemieszczenia $42,5 \mathrm{~mm}$, każde koło powinno przebiec drogę co najmniej o długości $S_{k}$ według rys. 3

$$
S_{k} \geq \frac{4,25}{\delta \%} \frac{D_{k}}{d_{b l}}[m]
$$

przy czym pochylenie $\beta$ listwy 13 (według rys. 1 i 3 ), w stosunku do osi toru powinno wynosić

$$
\beta \leq \delta \frac{d_{b l}}{D_{k}}
$$

Przykładowo, przyjęcie $\delta=3 \%, d_{b l}=0,22 \mathrm{~m}$ oraz $D_{k}=1 \mathrm{~m}$ oznaczałoby, że dla wyczerpania przemieszczenia poosiowego $0,0425 \mathrm{~m}$, każde koło biegowe powinno przebiec ok. $6,44 \mathrm{~m}$ przy listwie 13 (rys. 1) pochylonej pod katem $0,66 \%$ czyli $0,378^{\circ}$.

\section{Konkluzje końcowe}

Zarówno dane literaturowe jak i wykonane pomiary wykazują zgodny charakter przyrostu wartości kąta $\delta$ wraz z przyrostem wartości siły $F_{y}$.

Pomiary wykonane na modelowym obiekcie fizycznym wykazały, że układ statycznie samohamowny, przy narzuconym ruchu obrotowym wałka 2 , już przy poosiowym obciążeniu siłą nie przekraczająca wartości 3-10\% obciążenia promieniowego, z łatwością osiaga technicznie satysfakcjonującą wartość kąta $\delta \approx 3 \%$ odchylenia trajektorii na bieżniach rolek.

Ze wzrostem obciążenia promieniowego rolek siła $F$, rośnie kąt $\delta$ odchylenia trajektorii ruchu rolki aż do osiagnięcia wartości granicznej (w pracy [3] było to $\sim 10^{\circ} \approx 17,6 \%$ ) odpowiadającej współczynnikowi poosiowego tarcia rolek, kiedy łożysko rolkowe traci swą techniczną funkcję i zaczyna pracować jak panewka.

Przeprowadzona analiza sprężystych odkształceń postaciowych rolki wykazała technicznie znikomy wpływ tych odkształceń na ruchowe odchylenie trajektorii rolki obciążonej poosiowo. Porównawczo, dla rolki o średnicy $2 R$, teoretyczny kąt sprężystego pochylenia linii śrubowej wynosi zaledwie $6,31 \cdot F / Q$. $10^{-8}[\%]$. W kolejowej praktyce inżynierskiej zjawisko to $\mathrm{w}$ większości przypadków może być ignorowane.

Ze względu na ograniczone ramy objętościowe, dość prymitywne warunki eksperymentu, oraz brak analizy podobieństwa geometrycznego, niniejsze opracowanie może mieć znaczenie głównie dydaktyczno-inspiracyjne oraz metodyczne. Dla potrzeb przemysłowych wyniki liczbowe powinny zostać potwierdzone na drodze szczegółowych symulacji [4] oraz uwiarygodnione pomiarami na profesjonalnym stanowisku badawczym.

\section{Li ter a tura}

[1] Opis patentowy B1 201613 z dnia 30.04.2009: „Zestaw kołowy dla pojazdów szynowych o zmiennym rozstawie kót" Twórcy wynalazku: Jerzy Madej, Marian Medwid, Włodzimierz Stawecki, Zdzisław Pawlak.

[2] Opis patentowy B1 202614 z dnia 31.07.2009: „Zestaw kołowy dla pojazdów szynowych o zmiennym rozstawie kót" Twórcy wynalazku: Jerzy Madej, Marian Medwid, Włodzimierz Stawecki, Zdzisław Pawlak.

[3] Krempel G., Untersuchungen an Kratfahrzeugrefen, Automobiltechnische Zeitschrift 1967, 60(8), pp. 262-268.

[4] P iotrowski J., Kalker's algorithm Fastsim solves tangential contact problems with slip-dependent friction and friction anisotropy, Vehicle Systems Dynamics, Vol. 48, No. 7, July 2010, 869-889. 